\title{
Effects of Irrigation and Planting Geometry on Soybean (Glycine $\max$ L.) Seed Nutrition in Humid Climates
}

\author{
Srinivasa R. Pinnamaneni ${ }^{D},{ }^{1}$ Saseendran S. Anapalli ${ }^{D},{ }^{1}$ Nacer Bellaloui, ${ }^{2}$ \\ and Krishna N. Reddy ${ }^{3}$ \\ ${ }^{1}$ USDA-ARS, Sustainable Water Management Research Unit, Stoneville, MS 38776, USA \\ ${ }^{2}$ USDA-ARS, Crop Genetics Research Unit, Stoneville, MS 38776, USA \\ ${ }^{3}$ USDA-ARS, Crop Production Systems Research Unit, Stoneville, MS 38776, USA
}

Correspondence should be addressed to Srinivasa R. Pinnamaneni; sri.pinnamaneni@usda.gov

Received 18 December 2020; Revised 8 April 2021; Accepted 3 May 2021; Published 18 May 2021

Academic Editor: Othmane Merah

Copyright (c) 2021 Srinivasa R. Pinnamaneni et al. This is an open access article distributed under the Creative Commons Attribution License, which permits unrestricted use, distribution, and reproduction in any medium, provided the original work is properly cited.

\begin{abstract}
This study investigates the effect of irrigation (FI, all rows-irrigation; HI, alternate row irrigation; RF, rainfed) and planting geometry (PG) (SR, single-row; TR, twin-row) on soybean seed constituents. Results showed that most of these seed components were significantly affected by crop season due to contrasting precipitation and solar radiation patterns, particularly during JulyAugust, coinciding with early reproductive and seed development stages. Both seed protein and oil levels responded positively to irrigation, while most of the amino acids were nonresponsive. The protein content ranged between 36.3 and $37.6 \%$ in 2018 , while it was between 36.4 and $38.3 \%$ in 2019. Total seed oil content varied between 24.2 and $26.1 \%$ in 2018 and between 25.3 and $26.5 \%$ in 2019. Among amino acids, glycine, alanine, valine, and methionine levels were significantly higher in both FI and HI treatments. Among sugars, only sucrose was higher in response to the RF treatment, and irrigation did not affect both stachyose and raffinose. Oleic acid was higher in RF, while no significant differences were observed for linolenic and linoleic acids. Similarly, seasonal variation was significant for stearic acid content, but the 2019 season had relatively higher accumulation (stearic acid: between 4.1 and $4.5 \%$ in 2018 and from 4.6 to $4.9 \%$ in 2019). These results indicate that both irrigation and climate during seed development can alter some seed composition constituents and play critical roles in determining seed nutritional qualities.
\end{abstract}

\section{Introduction}

Soybean (Glycine max (L.) Merr.) is an important food legume crop worldwide, providing vegetable protein for millions of people and ingredients for hundreds of food and nonfood products. The seeds provide approximately $60 \%$ of the global supply of vegetable protein and are a good substitute for animal protein. The global area of soybeans in 2018 was 125.3 million ha with a production of 360 million tons $(\mathrm{t})$ of grain at an average yield of $2.88 \mathrm{t} \mathrm{ha}^{-1}$. The United States accounts for about 35.45 million ha with a production of 240 million $\mathrm{t}$ and a productivity of $3.4 \mathrm{t} \mathrm{ha}^{-1}$ [1]. About 60 percent of US soybeans are exported worldwide, while the rest is processed for domestic consumption. However, regardless of where they are used, the vast majority are crushed to separate the seed's protein and oil. Soybean seed contains about $30-45 \%$ high-quality protein with essential amino acids and $15-22 \%$ oil with a high proportion of unsaturated fatty acids.

Soybean seed contains about 10\% palmitic acid (C16:0), $4 \%$ stearic acid (C18:0), 22\% oleic acid (C18:1), 54\% linoleic acid (C18:2), and 10\% linolenic acid (C18:3) [2]. Higher levels of protein and oil are desirable since their key contribution to better soybean quality and higher oil industry profitability. Deep-pot frying with soybean oil results in the hydrogenation of unsaturated fatty acids, particularly polyunsaturated fatty acids like linoleic (C18:2) and linolenic acids (C18:3), which is linked to the enhanced incidence of heart disease [3]. Hence, the food and seed oil industry are leaning towards soybean with high oleic acid and low 
linolenic acid due to their contribution to soybean oil's oxidative stability [2]. Similarly, as higher levels of palmitic acid led to oxidative instability, its reduced levels $\left(40 \mathrm{~g} \mathrm{Kg}^{-1}\right)$ are preferred by the industry for human consumption. Among sugars, both raffinose and stachyose are undesirable to the soybean food industry due to their indigestibility leading to flatulence and, in some cases, diarrhea. At the same time, higher sucrose is preferred as it improves taste and flavor in soy-based foods [4].

Traditionally, soybean was cultivated on single rows (SR) on raised seedbeds. Many producers in Mississippi and adjoining states in the Midsouth in recent years have shifted from the SR planting to a twin-row (TR) planting geometry (PG) owing to enhanced productivity and operational feasibility [5-8]. The rows are separated by $102 \mathrm{~cm}$ in the SR system, while $25 \mathrm{~cm}$ spaced two rows planted on a flattened ridge are separated by $102 \mathrm{~cm}$ in the TR system. Over $60 \%$ of soybean acreage is currently irrigated in the Mississippi Delta region to stabilize farm productivity, as the large interseasonal and intraseasonal variability in precipitation during the crop season (April-September) are limiting the yields [9]. Both PG and irrigation are two key crop management practices for optimizing seed yield in the Midsouth $[8,10]$. However, their effects on seed composition (protein, oil, fatty acids, sugars, and amino acids) in soybean in the Midsouth are limited. It was reported that irrigation had affected significantly seed protein and oil. Protein levels increased with irrigation, while oil content was higher in the nonirrigated crop but was subject to year wise and cultivar differences [11]. Another study conducted in Tennessee demonstrated that row spacing had significantly altered seed constituents like protein, oil, and sugars but environmental factors like heat and drought had a much more profound effect [5]. Both seeding rate and row spacing affected the seed composition, and high variation among the years of study was observed due to incident variability in the temperatures and drought [6]. The different responses of seed composition, including protein, oil, and fatty acids, to temperature and drought, have also been previously reported by [11-13]. A similar study on cotton reported variable response for seed constituents to moisture and row spacing [14].

Although limited information is available on the effects of irrigation, drought, and PG, on seed composition, to our knowledge, there has been limited research done on the combined effects of irrigation and PG on seed composition. Therefore, the objective of the current study was to evaluate the effects of SR and TR plantings with three levels of irrigation (FI, HI, and RF) on soybean seed composition in silt loams soil of the Mississippi Delta. This is a unique study reporting the interaction of skipped row irrigation (HF) with row spacing, which has more relevance as the significant number of producers has switched to TR planting in Mississippi Delta in the recent past. We hypothesized that (1) the PG combined with different irrigation levels will subject the crop to a new growing microenvironment, as TR pattern results in early canopy closure and high light interception, and (2) increases in carbon assimilation and nutrients uptake rates can impact favorably higher accumulation of seed protein, oils, sugars, and amino acids.

\section{Materials and Methods}

2.1. Field Conditions and Crop Management. The two-year (2018-2019) field experiments were undertaken at the USDA-ARS Crop Production Systems Research Unit Farm, Stoneville, Mississippi, USA ( $33^{\circ} 42^{\prime} \mathrm{N}, 90^{\circ} 55^{\prime} \mathrm{W}$, elevation: $32 \mathrm{~m}$ above mean sea level) on a Dundee silt loam (fine silty, mixed, active, thermic Typic Endoaqualfs) soil. The physical and health parameters of the top $15 \mathrm{~cm}$ soil of the experimental field are given in Table 1 . The field saturated hydraulic conductivity ranged between 0.52 and $1.49 \mathrm{~cm} \mathrm{hr}^{-1}$ (Saturo infiltrometer, METER Group, Inc., USA).

Soybean cultivar "31RY45 Dyna-Gro" (maturity group IV) was planted in a split-plot design with six replicates. The main plots were three irrigation regimes (i) FI, (ii) HI, and (iii) RF, while the subplots consisted of two planting geometries: (i) SR, single rows evenly spaced at $102 \mathrm{~cm}$ apart, and (ii) TR, two rows spaced at $25 \mathrm{~cm}$ apart on $102 \mathrm{~cm}$ centered seedbeds. The tests were planted on May 8, 2018, and May 2, 2019. Each plot size was $40 \mathrm{~m} \times 3.9 \mathrm{~m}$. The details of field preparation, planting, irrigation, crop management, and sample collection were described by Pinnamaneni et al. [7]. Weather data were collected from the nearest weather station, that is, Mid-South Agricultural Weather Service, Delta Research and Extension Center, Stoneville, Mississippi. The amount of precipitation received during the 2018 crop season (April-September) was $730.76 \mathrm{~mm}$, while $895.60 \mathrm{~mm}$ was received in the 2019 season. The growing degree days (GDD) in ${ }^{\circ} \mathrm{C}$ were calculated using a base temperature (T base) of $10^{\circ} \mathrm{C}[15]$. The crop was harvested after physiological maturity with a combine, and grain yields per ha were computed.

2.2. Seed Protein, Oil, Fatty Acids, and Sugars Analyses. About $25 \mathrm{~g}$ of mature and dry seeds collected at the R8 stage was ground by a Laboratory Mill 3600 (Perten, Springfield, IL). The protein, oil, fatty acids, and sugars (sucrose, raffinose, and stachyose) contents were quantified using a Diode Array Feed Analyzer AD 7200 (Perten, Springfield, IL). Seed analyses were conducted according to Xue et al. [16]. The updated calibration equation used was from Perten's Thermo Galactic Grams PLS IQ software, which was initially developed at the University of Minnesota and then upgraded by the Perten Company. The calibration equations were established based on laboratory protocols according to Association of Official Analytical Chemists (AOAC) methods [17]. Fatty acids (palmitic, stearic, oleic, linoleic, and linolenic) were expressed on a total oil basis. Protein, oil, and sugars (sucrose, raffinose, and stachyose) were expressed on a dry matter basis [18]. 
TABLE 1: Selected soil chemical properties of research fields used for studies in Stoneville, MS, USA, in 2018 and 2019.

\begin{tabular}{|c|c|c|c|c|c|c|c|c|c|c|c|c|c|c|}
\hline \multirow{2}{*}{ Year } & \multirow{2}{*}{$\begin{array}{c}\text { Soil } \\
\text { depth }\end{array}$} & \multirow{2}{*}{$\begin{array}{l}\text { Soil } \\
\text { texture }\end{array}$} & \multirow{2}{*}{ Soil description } & \multirow{2}{*}{$\mathrm{p}^{\mathrm{H}}$} & \multirow{2}{*}{$\begin{array}{c}\text { Organic } \\
\text { matter } \\
\%\end{array}$} & \multirow{2}{*}{$\begin{array}{c}\text { Nitrogen } \\
\%\end{array}$} & \multirow{2}{*}{$\begin{array}{l}\text { CEC } \\
\text { Meq } \\
100 \mathrm{~g}^{-1}\end{array}$} & \multirow{2}{*}{$\begin{array}{c}\mathrm{P} \\
\mathrm{ppm}\end{array}$} & \multirow{2}{*}{$\begin{array}{c}\mathrm{K} \\
\mathrm{Mg} \cdot \mathrm{Kg}^{-1}\end{array}$} & \multirow{2}{*}{$\begin{array}{r}\mathrm{Ca} \\
\mathrm{ppm}\end{array}$} & \multirow{2}{*}{$\begin{array}{r}\mathrm{Mg} \\
\mathrm{ppm}\end{array}$} & \multirow{2}{*}{$\begin{array}{c}\mathrm{Zn} \\
\mathrm{ppm} \\
\end{array}$} & \multirow{2}{*}{$\begin{array}{c}\mathrm{S} \\
\mathrm{ppm}\end{array}$} & \multirow{2}{*}{$\begin{array}{l}\mathrm{Cu} \\
\mathrm{ppm}\end{array}$} \\
\hline & & & & & & & & & & & & & & \\
\hline 2018 & $0-6^{\prime \prime}$ & Loam & $\begin{array}{l}\text { Dundee silt } \\
\text { loam }\end{array}$ & 6.75 & 1.23 & 0.05 & 9.2 & 32 & 156 & 1168 & 246 & 1.6 & 6.1 & 1.4 \\
\hline 2018 & $6-12^{\prime \prime}$ & Loam & “ & 6.79 & 1.2 & 0.06 & 13.4 & 19 & 142 & 1758 & 292 & 1.4 & 5.9 & 1.8 \\
\hline 2019 & $0-6^{\prime \prime}$ & Loam & $\begin{array}{l}\text { Dundee silt } \\
\text { loam }\end{array}$ & 6.83 & 1.24 & 0.05 & 8.2 & 27 & 119 & 1003 & 226 & 1.5 & 5.6 & 1.3 \\
\hline 2019 & $6-12^{\prime \prime}$ & Loam & " & 6.77 & 1.21 & 0.05 & 12.9 & 17 & 133 & 1617 & 296 & 1.4 & 5.8 & 2 \\
\hline
\end{tabular}

2.3. Seed Amino Acids Analyses. The amino acid content was estimated using a near-infrared (NIR) reflectance diode array feed analyzer (Perten, Springfield, IL) according to the published protocols $[16,18]$ on mature dry seeds. Individual amino acids arginine (ARG), alanine (ALN), asparagine (ASP), cysteine (CYS), glutamine (GLU), glycine (GLY), histidine (HIS), isoleucine (ISO-LEU), lysine (LYS), leucine (LEU), methionine (MET), phenylalanine (PHE), proline (PRO), serine (SER), tryptophan (TRY), threonine (THR), tyrosine (TYR), and valine (VAL) were analyzed $[19,20]$. The calibration equation was initially developed by the Department of Agronomy and Plant Genetics, University of Minnesota, St Paul, MN, using Thermo Galactic Grams PLS IQ software developed by the Perten Company (Perten, Springfield, IL). The quantification equation was established using laboratory protocols according to the AOAC sample spectra, resulting in accurate estimations of amino acid quantification. Amino acid content was expressed on a dry matter basis (\%).

2.4. Statistical Analyses. Data were subjected to analysis of variance (ANOVA) using PROC MIXED in Statistical Analysis System (SAS ${ }^{\circledR}$ version 9.4; SAS Institute Inc., Cary, $\mathrm{NC}$ ). Replicate within the year was considered as random effects. The year, irrigation, PG, and their interactions were considered as fixed effects and replication and whole plot (irrigation) were considered as random effects. Random effects used in this model for the comparison across years were irrigation $X$ year, PG $X$ year, and irrigation $X$ PG $X$ year. Treatment means were separated at the $5 \%$ level of significance using Fisher's protected least significant difference (LSD) test. Because the interactions involving combinations of the year $(Y), P G$, and irrigation were significant for some seed composition constituents, results were presented separately by year.

\section{Results}

3.1. Weather Differences in the Crop Seasons. The weather parameters were significantly different during the two cropping seasons (April-September) of the study (Figures 1 and 2). The 2018 crop season received $147 \mathrm{~mm}$ rainfall during the June-July period compared to $273 \mathrm{~mm}$ in 2019, which coincided with flowering and early pod development (phenological stages, R1-R4). The month of August coincided with pod maturation (R4-R8) and the 2018 season had
2.5 times higher rainfall than that of 2019 (231 mm in 2018 versus $92 \mathrm{~mm}$ in 2019). Though the growing season in 2018 received more rainfall, the rainfall received during the soybean vegetative growth period (May-July) in 2018 coincided with periods of lower rainfall $(375 \mathrm{~mm}$ lesser than that of 2019) higher mean minimum and maximum air temperatures. The peak flowering period (June-July) in 2018 recorded 51 additional GDD than in 2019 (782 in 2019 versus 833 in 2018). In the case of solar radiation, the reproductive phase (June-August) recorded significant differences among the two seasons (2018: $1131 \mathrm{MJ} \cdot \mathrm{m}^{-2} \cdot \mathrm{day}^{-1}$ versus 2019: $1548 \mathrm{MJ} \cdot \mathrm{m}^{-2} \cdot \mathrm{day}^{-1}$ ). These differences in weather during the two crop seasons, specifically during the reproductive phase, were reflected in the ANOVA tests for several of the seed composition traits between the 2018 and 2019 seasons (Tables 2 and 3 ).

3.2. ANOVA for Seed Composition Constituents. ANOVA (Tables 2 and 3) showed that irrigation, PG, year, and their interactions had significant effects on some seed composition components but not on others. For instance, irrigation levels had affected seed protein, oil, stearic acid, sucrose, and several amino acids (THR, GLU, GLY, ALA, TYR, VAL, and MET (Tables 2 and 3). However, PG had affected stearic acid and sucrose besides most of the amino acids. Year affected all the traits studied, except for PRO, LEU, and ARG. This is probably attributable to the high variation in rainfall, temperature, solar radiation, and GDD among the two crop seasons coinciding with the flowering and pod development and seed maturation (Figures 1 and 2). The interactions were mostly nonsignificant except for irrigation and PG affecting ASP and CYS, while the interaction effect of irrigation and year was significant for protein.

3.2.1. Seed Constituents as Influenced by Irrigation. Irrigation and TR-PG had a favorable effect on seed yield in both years, as reported by Pinnamaneni et al. [7]. The average grain yields among the irrigation and PG treatments were FI: $4.8 \mathrm{Mg} \mathrm{ha}^{-1}$ in TR versus 4.2 in $\mathrm{Mg} \cdot \mathrm{ha}^{-1}$ in SR; HI: $4.7 \mathrm{Mg} \cdot \mathrm{ha}^{-1}$ in TR versus $4.1 \mathrm{Mg} \cdot \mathrm{ha}^{-1}$ in SR while in RF-TR yielded $4.1 \mathrm{Mg} \cdot \mathrm{ha}^{-1}$, and the lowest yield was recorded in RFSR: $3.6 \mathrm{Mg} \cdot \mathrm{ha}^{-1}$.

(i) Seed Protein. The irrigated treatments recorded 2.3\% higher protein in 2018 and 1.8\% higher in 2019 compared to 


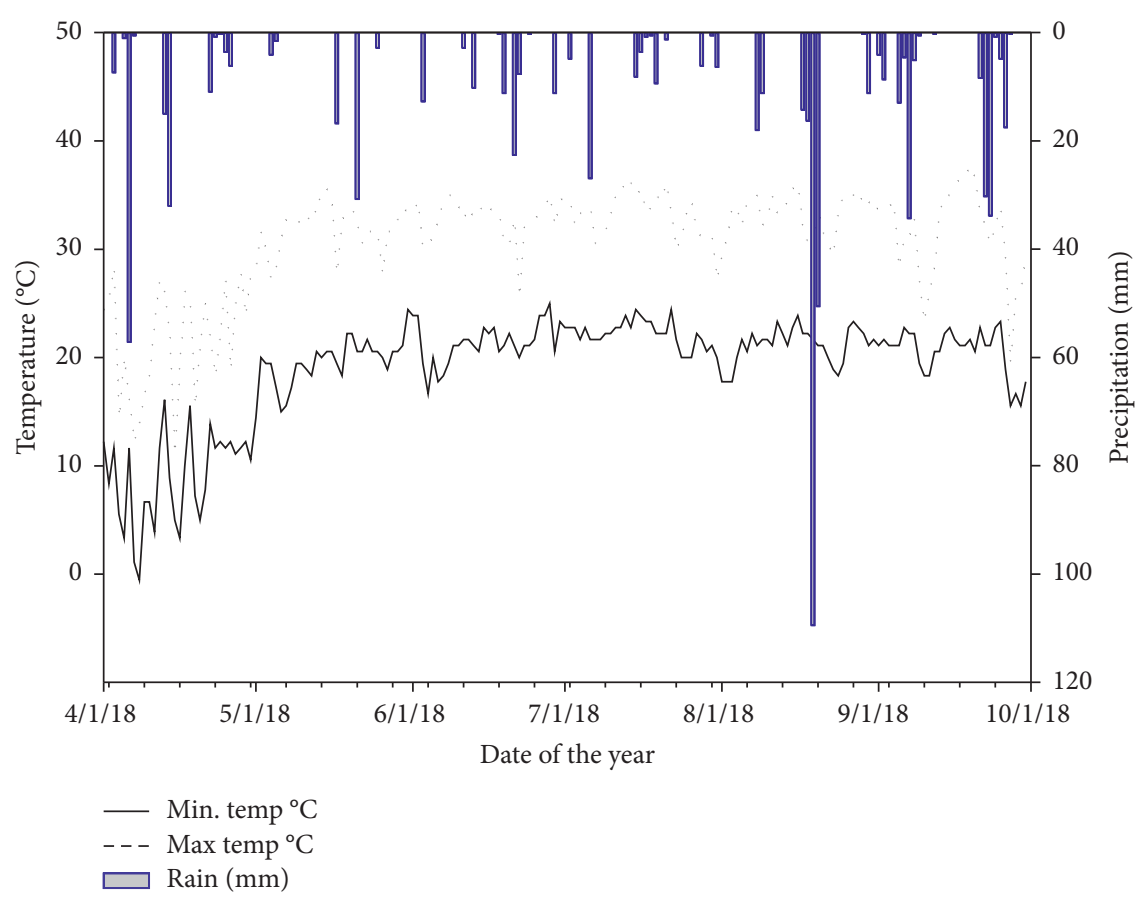

(a)

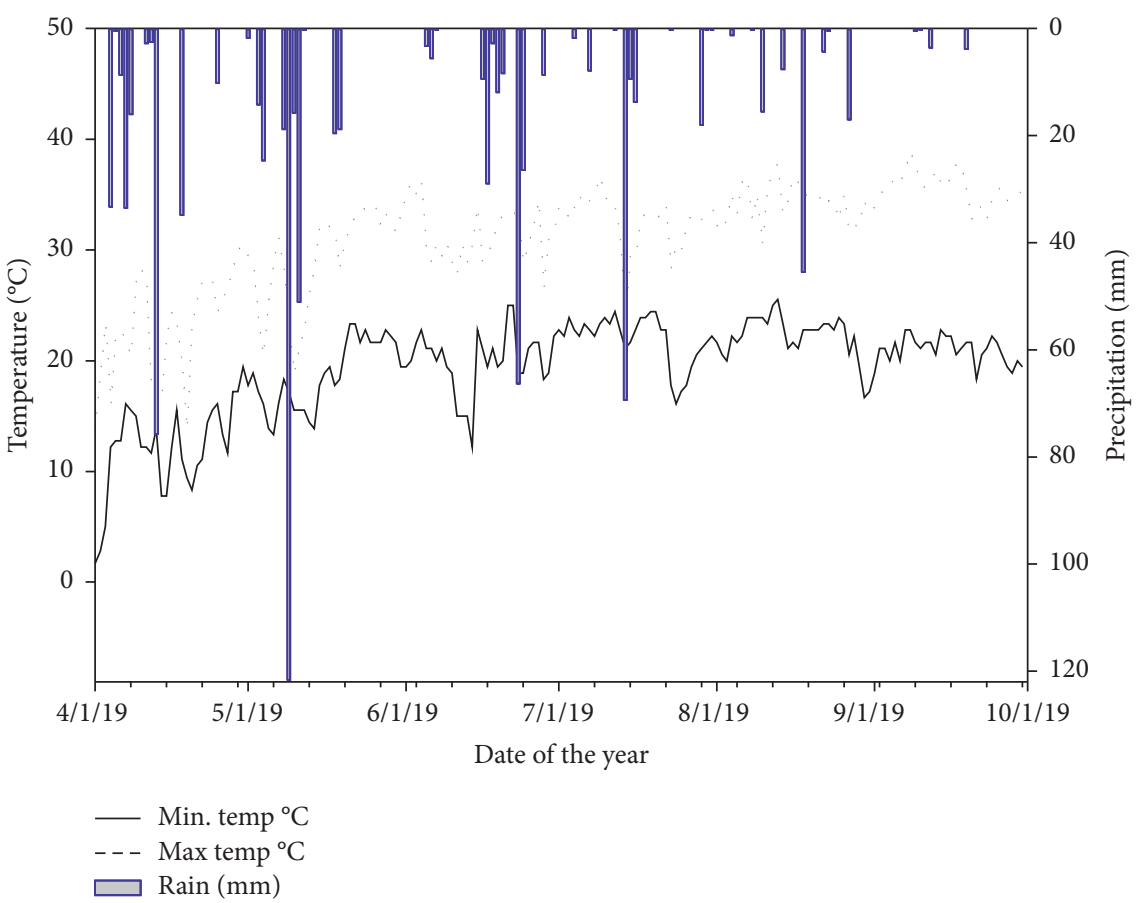

(b)

FIGURE 1: Measured air temperature and precipitation in 2018 and 2019 soybean growing seasons at Stoneville, MS, USA. (a) 2018 and (b) 2019 .

RF. The most rapid accumulation of protein in seed occurs between 20 and 40 days after flowering but continues till 70 days after flowering [21]. As there was well-distributed rainfall during August 2019, the differences in protein content among RF, HI, and FI treatments were less pronounced. The protein content ranged from 36.3 to $37.6 \%$ in
2018 and from 36.4 to $38.3 \%$ in 2019 , indicating the crop season differences in weather conditions (Table 4).

(ii) Oil and Fatty Acids. Seed oil deposition starts 15-20 after flowering based on the cultivar and weather conditions. Irrigation has an inverse relationship with seed oil accumulation, in contrast to seed protein accumulation. Total 


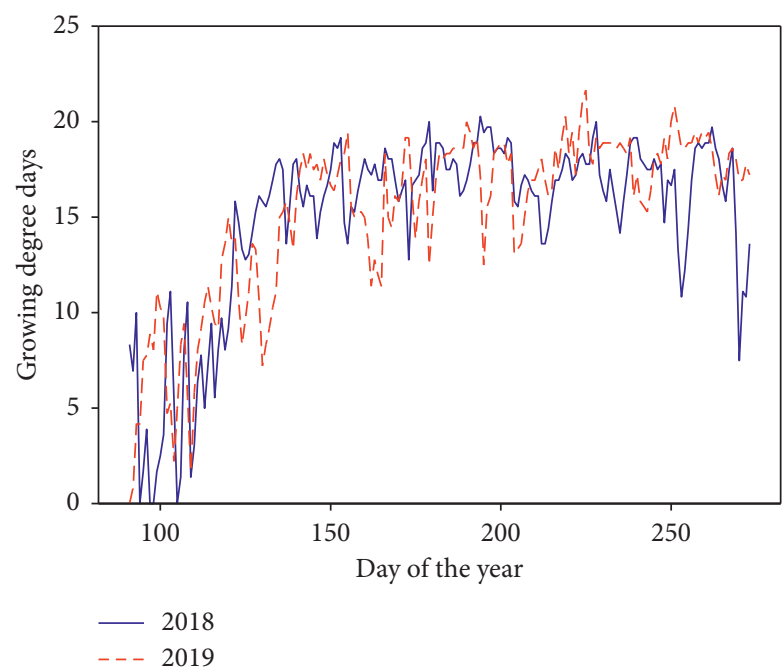

(a)

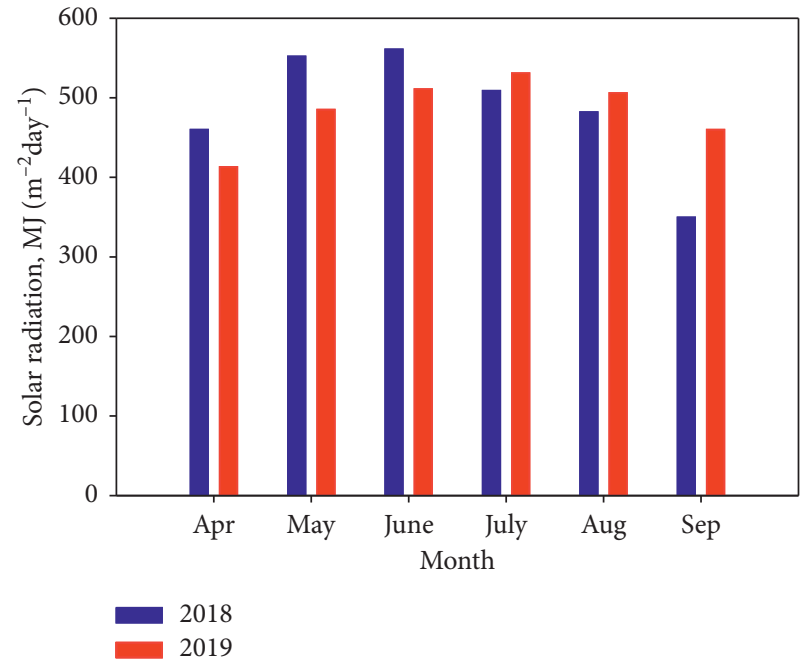

(b)

Figure 2: Measured (a) growing degree days (GDD) and (b) solar radiation in 2018 and 2019 soybean growing seasons at Stoneville, MS, USA.

TABLE 2: Significance of the main effects of irrigation regimes, year, and planting geometry (PG) and their interactions on seed composition traits at Stoneville, MS, during 2018-2019 crop seasons.

\begin{tabular}{|c|c|c|c|c|c|c|c|c|c|c|c|c|c|c|}
\hline $\begin{array}{l}\text { Source of } \\
\text { variance }\end{array}$ & $\mathrm{d} f$ & Protein & Oil & $\begin{array}{l}\text { Palmitic } \\
\text { acid }\end{array}$ & $\begin{array}{c}\text { Stearic } \\
\text { acid }\end{array}$ & $\begin{array}{l}\text { Oleic } \\
\text { acid }\end{array}$ & $\begin{array}{c}\text { Linoleic } \\
\text { acid }\end{array}$ & $\begin{array}{l}\text { Linolenic } \\
\text { acid }\end{array}$ & Sucrose & Raffinose & Stachyose & Daidzin & Glycitin & Genistin \\
\hline $\begin{array}{l}\text { Irrigation } \\
\text { level }\end{array}$ & 2 & $*$ & $*$ & $*$ & ns & ns & ns & ns & $*$ & ns & ns & ns & ns & ns \\
\hline PG & 1 & ns & ns & ns & $*$ & ns & ns & ns & $*$ & ns & ns & ns & ns & ns \\
\hline Year & 1 & $*$ & $*$ & $*$ & $* *$ & $* *$ & $* *$ & $*$ & $* *$ & ns & $*$ & & & \\
\hline $\begin{array}{l}\text { Irrigation } \\
\text { level * PG }\end{array}$ & 2 & ns & ns & ns & ns & ns & ns & ns & ns & ns & ns & ns & ns & ns \\
\hline $\begin{array}{l}\text { Irrigation } \\
\text { level * } \\
\text { year }\end{array}$ & 2 & * & $\mathrm{ns}$ & ns & ns & ns & ns & ns & ns & ns & ns & & & \\
\hline $\begin{array}{l}\mathrm{PG}^{*} \text { year } \\
\text { Irrigation }\end{array}$ & 1 & ns & ns & ns & * & ns & ns & $\mathrm{ns}$ & ns & ns & $\mathrm{ns}$ & & & \\
\hline $\begin{array}{l}\text { level * PG } \\
* \text { year }\end{array}$ & 2 & ns & $\mathrm{ns}$ & ns & ns & ns & ns & ns & ns & ns & ns & & & \\
\hline
\end{tabular}

TABLE 3: Significance of the main effects of irrigation regimes, year, and PG and their interactions on seed composition traits at Stoneville, MS, during 2018-2019 crop seasons.

\begin{tabular}{|c|c|c|c|c|c|c|c|c|c|c|c|c|c|c|c|c|c|c|c|}
\hline Source of variance & $\mathrm{d} f$ & ASP & THR & SER & GLU & $\mathrm{PRO}$ & GLY & ALA & CYS & VAL & MET & ISO & LEU & TYR & $\mathrm{PHE}$ & LYS & HIS & ARG & TRY \\
\hline Irrigation level & 2 & * & ns & ns & $* *$ & ns & $*$ & ns & * & ns & ns & ns & ns & $*$ & ns & ns & ns & ns & * \\
\hline$P G$ & 1 & $*$ & $*$ & ns & $*$ & ns & * & ns & * & ns & ns & $*$ & $*$ & ns & ns & ns & ns & $*$ & * \\
\hline Year & 1 & * & $* *$ & $*$ & * & ns & $* *$ & $* *$ & * & $* *$ & $* *$ & $*$ & ns & $* *$ & $* *$ & $* *$ & $*$ & ns & * \\
\hline Irrigation level ${ }^{*} \mathrm{PG}$ & 2 & * & ns & ns & ns & ns & ns & ns & * & ns & ns & ns & ns & ns & ns & ns & ns & ns & ns \\
\hline Irrigation level ${ }^{*}$ year & 2 & ns & ns & ns & ns & ns & ns & ns & ns & ns & ns & ns & ns & ns & ns & ns & ns & ns & ns \\
\hline $\mathrm{PG}^{*}$ year & 1 & ns & $*$ & ns & ns & ns & $*$ & ns & ns & ns & ns & ns & ns & ns & ns & ns & ns & ns & ns \\
\hline $\begin{array}{l}\text { Irrigation level }{ }^{*} \mathrm{PG} \\
* \text { year }\end{array}$ & 2 & ns & ns & ns & $\mathrm{ns}$ & ns & ns & ns & ns & ns & ns & ns & ns & ns & ns & $\mathrm{ns}$ & ns & ns & ns \\
\hline
\end{tabular}

ns: nonsignificant. * Significantly different at $P \leq 0.05$ level. ${ }^{* *}$ Significantly different at $P \leq 0.01$ level. 
TABLE 4: Effect of irrigation treatments (FI, HI, and RF) and PG (single-row (SR) and twin-row (TR) planting) on soybean seed protein: oil, palmitic (C16:0), stearic (C18:0), oleic (C18:1), linoleic (C18:2), linolenic (C18:3), and sugars (sucrose, raffinose, and stachyose).

\begin{tabular}{|c|c|c|c|c|c|c|c|c|c|c|c|c|c|c|c|}
\hline \multirow[t]{2}{*}{ Treatment } & \multirow[t]{2}{*}{ PG } & \multicolumn{2}{|c|}{ Protein (\%) } & \multicolumn{2}{|c|}{ Oil (\%) } & \multicolumn{2}{|c|}{ Palmitic acid } & \multicolumn{2}{|c|}{ Stearic acid } & \multicolumn{2}{|c|}{ Oleic acid } & \multicolumn{2}{|c|}{ Linoleic acid } & \multicolumn{2}{|c|}{$\begin{array}{l}\text { Linolenic } \\
\text { acid }\end{array}$} \\
\hline & & 2018 & 2019 & 2018 & 2019 & 2018 & 2019 & 2018 & 2019 & 2018 & 2019 & 2018 & 2019 & 2018 & 2019 \\
\hline \multirow{2}{*}{ FI } & SR & $37.6 a$ & $37.4 \mathrm{~b}$ & $24.5 c$ & & $9 \mathrm{a}$ & & & & 25.7 & & 55.7 & & 7.2 & 5.8 \\
\hline & TR & $37.3 \mathrm{ab}$ & $36.6 \mathrm{~b}$ & $25 b$ & $25.3 \mathrm{~d}$ & $8.9 a$ & $9.5 \mathrm{bc}$ & $4.5 \mathrm{a}$ & $4.7 \mathrm{bc}$ & 26.5 & 25.5 & 58.5 & 57.5 & 7 & 5.3 \\
\hline \multirow{2}{*}{ HI } & SR & $37.3 \mathrm{ab}$ & $38.3 a$ & $24.2 \mathrm{c}$ & $26.2 b$ & $8.4 \mathrm{c}$ & $9.4 c$ & $4.1 \mathrm{~b}$ & $4.8 \mathrm{a}$ & 26.7 & 25.9 & 58.7 & 56.9 & 5.7 & 6.1 \\
\hline & TR & $36.7 \mathrm{~b}$ & $36.6 \mathrm{~b}$ & $25.5 \mathrm{~b}$ & $26 \mathrm{~b}$ & $8.6 \mathrm{~b}$ & $9.5 \mathrm{bc}$ & $4.3 \mathrm{a}$ & $4.9 \mathrm{a}$ & 26.8 & 25.8 & 58 & 56.8 & 6.7 & 5.8 \\
\hline \multirow[b]{2}{*}{$\mathrm{RF}$} & SR & $36.6 b$ & $36.8 \mathrm{~b}$ & $25.9 a$ & $26.1 \mathrm{~b}$ & $8.1 \mathrm{~d}$ & $9.5 b c$ & $4.2 \mathrm{~b}$ & $4.6 \mathrm{~b}$ & 28.5 & 26.3 & 58.5 & 56.3 & 6.2 & 5.9 \\
\hline & TR & $36.3 \mathrm{bc}$ & $36.4 \mathrm{c}$ & $26.1 \mathrm{a}$ & $26.5 \mathrm{a}$ & $8.3 c$ & $9.3 c$ & $4.4 \mathrm{a}$ & $4.8 \mathrm{a}$ & 27.7 & 26.6 & 57.7 & 55.6 & 6.8 & 5.8 \\
\hline
\end{tabular}

PG: planting geometry, FI: full irrigation, HI: half irrigation, and RF: rainfed. Means within each column followed by the same letter or letters are not statistically different by LSD means $(P \leq 0.05)$.

seed oil content varied from 24.2 to $26.1 \%$ in 2018 , while it ranged from 25.3 to $26.5 \%$ in 2019 (Table 4). However, among the saturated and unsaturated fatty acids in soybean seed, only palmitic acid was significantly affected by irrigation treatments as FI and $\mathrm{HI}$ had $6.4 \%$ and $1.6 \%$ higher accumulation than that of RF in 2018 and 2019, respectively (Table 3). The oleic, linoleic, and linolenic acid levels were higher in the 2019 season. Oleic acid ranged from 25.7 to $28.5 \%$ in 2018 and from 24.6 to $26.6 \%$ in 2019 , while linoleic acid varied from 55.7 to $58.5 \%$ in 2018 and from 55.6 to $57.5 \%$ in 2019 , indicating the seasonal variation. The linolenic acid ranged from 5.7 to $7.2 \%$ in 2018 and from 5.3 to $6.1 \%$ in 2019. Similarly, seasonal variation was significant for stearic acid content, but the 2019 season had relatively higher accumulation (stearic acid: $4.1-4.5 \%$ in 2018 versus $4.6-4.9 \%$ in 2019) (Table 4).

(iii) Sugars. The levels of sucrose, stachyose, and raffinose were quantified, and only irrigation had a significant inverse relationship with sucrose accumulation. RF soybean seed had 6.5\% in 2018 and 6\% in 2019 higher sucrose than FI and HI (Table 5). A significant interseasonal variation was observed for all three sugars.

(iv) Amino Acids. Out of the 18 amino acids quantified, only ASP, GLU, GLY, CYS, and TYR were significantly affected by irrigation. Both FI and HI irrigation treatments had accumulated significantly higher levels of these amino acids than the rainfed soybean, and the interseasonal variability is also significant (Table 3). The range for each of these amino acids year wise is ALA: 3.9-4 and 4.1-4.4; GLU: 3.6-4.0\% and 4.4-5.0\%; GLY: $2.8-3.1$ and 2.3-2.5\%; CYS: $024-0.32 \%$ and $0.29-0.35 \%$; TYR: $1.5-1.8 \%$ and $1.3-1.6 \%$ in 2018 and 2019, respectively (Tables 6 and 7).

3.2.2. Seed Constituents as Influenced by PG. Pinnamaneni et al. [7] have earlier reported that averaged across two seasons and three irrigation regimes, TR enhanced grain yield by $13 \%$ over SR ( $4.5 \mathrm{Mg}$ ha- 1 vs. $4.0 \mathrm{Mg}$ ha-1) due to better plant stand establishment and interception of photosynthetically active radiation.

(v) Seed Protein. PG did not affect seed protein content (Table 4).

(vi) Oil and Fatty Acids. PG did not influence the total oil content. However, only stearic acid was affected significantly
TABLE 5: Effect of irrigation treatments (FI, HI, and RF) and PG (SR and TR planting) on soybean seed: sugars (sucrose, raffinose, and stachyose).

\begin{tabular}{lccccccc}
\hline \multirow{2}{*}{ Treatment } & \multicolumn{4}{c}{ Sucrose } & \multicolumn{2}{c}{ Raffinose } & \multicolumn{2}{c}{ Stachyose } \\
& PG & 2018 & 2019 & 2018 & 2019 & 2018 & 2019 \\
\hline \multirow{2}{*}{ FI } & SR & $3.9 \mathrm{c}$ & $4.6 \mathrm{~b}$ & 0.78 & 0.76 & 3.6 & 3.7 \\
& TR & $4.4 \mathrm{~b}$ & $4.8 \mathrm{~b}$ & 0.74 & 0.77 & 3.9 & 3.6 \\
\hline \multirow{2}{*}{$\mathrm{HI}$} & SR & $3.9 \mathrm{c}$ & $4.4 \mathrm{c}$ & 0.72 & 0.77 & 3.9 & 3.2 \\
& TR & $4.5 \mathrm{a}$ & $4.5 \mathrm{a}$ & 0.75 & 0.80 & 3.9 & 3.5 \\
\hline \multirow{2}{*}{ RF } & SR & $4.4 \mathrm{~b}$ & $4.8 \mathrm{~b}$ & 0.73 & 0.76 & 3.7 & 3.5 \\
& TR & $4.5 \mathrm{a}$ & $4.9 \mathrm{a}$ & 0.75 & 0.74 & 3.9 & 3.6 \\
\hline
\end{tabular}

PG: planting geometry, FI: full irrigation, HI: half irrigation, and RF: rainfed. Means in each column followed by the same letter or letters are not statistically different by LSD means $(P \leq 0.05)$.

(2018: SR-4.1 and TR-4.4; 2019: SR-4.6 and TR-4.8). Palmitic acid, oleic acid, linoleic acid, and linolenic acid were not affected by PG (Table 4).

(vii) Sugars. Among sucrose, stachyose, and raffinose, only sucrose content was significantly and positively affected by TR geometry (2018: SR-4.2 and TR-4.4; 2019: SR-4.6 and TR-4.8) (Table 5).

(viii) Amino Acids. Among the quantified amino acids in both the crop seasons, only THR, GLU, GLY, CYS, ISO, LEU, ARG, and TRY were significantly affected in both years, while ASP was affected only in the 2019 season (Table 3). Except for THR, TR configuration had significantly and negatively impacted the accumulation of GLU, GLY, CYS, ISO, LEU, ARG, and TRY in both seasons (Tables 6 and 7).

\section{Discussion}

The seed constituents' accumulation pattern was significantly different for protein, oil, saturated and unsaturated fatty acids, sucrose, stachyose, and most of the amino acids except PRO, LEU, and ARG in the 2018 and 2019 crop seasons. The sugar and raffinose accumulation in multiple treatments was similar in both seasons, as an exception. These broad-spectrum differences among the seed components were not unexpected as the precipitation pattern, temperatures, GDD, and solar radiation were distinctly different. The mean daily temperatures in $2018\left(27.7^{\circ} \mathrm{C}\right.$ in 
TABLE 6: Effect of irrigation treatments (FI, HI, and RF) and PG (SR and TR planting) on soybean seed amino acids: aspartic acid (ASP), threonine (THR), serine (SER), and glutamic (GLU), proline (PRO), glycine (GLY), alanine (ALA), cystine (CYS), valine (VAL), methionine (MET), isoleucine (ISO), leucine (LEU), tyrosine (TYR), phenylalanine (PHE), and lysine (LYC).

\begin{tabular}{|c|c|c|c|c|c|c|c|c|c|c|c|c|c|c|c|c|c|c|c|}
\hline \multirow{2}{*}{ Treatment } & \multirow{2}{*}{ PG } & \multicolumn{2}{|c|}{ ASP } & \multicolumn{2}{|c|}{ THR } & \multicolumn{2}{|c|}{ SER } & \multicolumn{2}{|c|}{ GLU } & \multicolumn{2}{|c|}{ PRO } & \multicolumn{2}{|c|}{ GLY } & \multicolumn{2}{|c|}{ ALA } & \multicolumn{2}{|c|}{ CYS } & \multicolumn{2}{|c|}{ VAL } \\
\hline & & 2018 & 2019 & 018 & 2019 & 018 & 2019 & 2018 & 2019 & 2018 & 2019 & 2018 & 2019 & 2018 & 2019 & 018 & 2019 & 2018 & 2019 \\
\hline & SR & $4.1 \mathrm{a}$ & & $.9 \mathrm{~b}$ & & & & $4 d$ & & 2.3 & & & & & & $32 a$ & & & 2.2 \\
\hline & TR & 4.1a & 4 & $2 \mathrm{a}$ & $1.8 \mathrm{ab}$ & 2.4 & & $3.9 \mathrm{a}$ & $4.4 \mathrm{~d}$ & 2. & & $3.0 \mathrm{~b}$ & & & & $0.26 \mathrm{~b}$ & & & .3 \\
\hline \multirow{2}{*}{$\mathrm{HI}$} & SR & $4 \mathrm{ab}$ & 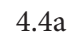 & $2 a$ & $1.7 \mathrm{~b}$ & 2.4 & 2. & $3.8 \mathrm{~b}$ & 5. & 2.3 & 23 & $3.0 \mathrm{~b}$ & 2 & 2 & & $0.24 \mathrm{c}$ & $\mathrm{a}$ & 25 & 2.3 \\
\hline & TR & $3.9 \mathrm{~b}$ & $4.2 \mathrm{~b}$ & $2.1 \mathrm{a}$ & $1.8 \mathrm{ab}$ & 2.4 & 2. & $3.5 \mathrm{~d}$ & $4.4 \mathrm{~d}$ & 2.3 & & $3.1 \mathrm{a}$ & & 2.0 & & $0.25 b$ & & 2.5 & .3 \\
\hline \multirow{2}{*}{ RF } & SR & 3.91 & & $1.9 \mathrm{~b}$ & & 2 & & c & 4. & 2 & & 2. & & 2 & & & & & 2.2 \\
\hline & TR & $3.9 \mathrm{~b}$ & $4.1 \mathrm{c}$ & $2 a$ & $1.9 \mathrm{a}$ & 2.3 & 2.1 & $3.6 c$ & $4.6 c$ & 2.2 & 2.2 & $2.9 c$ & $2.3 c$ & 2.0 & 1.8 & $0.26 \mathrm{~b}$ & $0.30 c$ & 2.5 & 2.2 \\
\hline
\end{tabular}

PG: planting geometry, FI: full irrigation, HI: half irrigation, and RF: rainfed. Means followed by the same letter or letters are not statistically different by LSD means $(P \leq 0.05)$.

TABLE 7: Effect of irrigation treatments (FI, HI, and RF) and PG (SR and TR planting) on soybean seed amino acids: methionine (MET), isoleucine (ISO), leucine (LEU), tyrosine (TYR), phenylalanine (PHE), lysine (LYS), histidine (HIS), arginine (ARG), and tryptophan (TRY) (\%).

\begin{tabular}{|c|c|c|c|c|c|c|c|c|c|c|c|c|c|c|c|c|c|c|c|}
\hline \multirow{2}{*}{ Treatment } & \multirow{2}{*}{ PG } & \multicolumn{2}{|c|}{ MET } & \multicolumn{2}{|c|}{ ISO } & \multicolumn{2}{|c|}{ LEU } & \multicolumn{2}{|c|}{ TYR } & \multicolumn{2}{|c|}{ PHE } & \multicolumn{2}{|c|}{ LYS } & \multicolumn{2}{|c|}{ HIS } & \multicolumn{2}{|c|}{ ARG } & \multicolumn{2}{|c|}{ TRY } \\
\hline & & 2018 & 2019 & 018 & 2019 & 018 & 2019 & 2018 & 2019 & 2018 & 2019 & 2018 & 2019 & 2018 & 2019 & 2018 & 2019 & 2018 & 2019 \\
\hline \multirow{2}{*}{ FI } & & 0.69 & 0 & 201 & & 253 & 0 & 183 & & & & 2 & & & & 889 & & $.43 a$ & $0.44 \mathrm{~b}$ \\
\hline & 1 & 0.7 & 0. & $1.8 \mathrm{c}$ & & $2.4 \mathrm{~b}$ & & & & & & & & & & & & & \\
\hline \multirow{2}{*}{$\mathrm{HI}$} & & 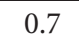 & O & 10 & & $2.4 \mathrm{~b}$ & 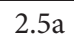 & 180 & & 17 & 2.0 & 2.2 & & & & 0 & & $42 b$ & $0.45 \mathrm{a}$ \\
\hline & $\mathrm{TH}$ & 0.7 & 0.62 & $1.7 \mathrm{~d}$ & $1 . / \mathrm{D}$ & $2.3 \mathrm{c}$ & $2.4 \mathrm{D}$ & $1.7 \mathrm{~b}$ & $1.4 \mathrm{C}$ & 1.8 & & 2.2 & & 0.5 & & $2.7 \mathrm{~b}$ & $2.7 \mathrm{~b}$ & $0.41 \mathrm{c}$ & $0.43 c$ \\
\hline \multirow{2}{*}{ RF } & 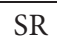 & 0.7 & & 10 & & 241 & & 160 & & & & & & & & $2.6 \mathrm{~b}$ & & Ic & 045 \\
\hline & TR & 0.7 & 0.61 & $1.7 \mathrm{~d}$ & $1.7 \mathrm{~b}$ & $2.3 \mathrm{c}$ & $2.4 \mathrm{~b}$ & $1.5 \mathrm{~d}$ & $1.3 \mathrm{~d}$ & 1.7 & 1.9 & 2.2 & 2.5 & 1.0 & 1.3 & $2.5 \mathrm{c}$ & $2.7 b$ & $0.40 \mathrm{~d}$ & $0.43 c$ \\
\hline
\end{tabular}

PG: planting geometry, FI: full irrigation, HI: half irrigation, and RF: rainfed. Means in each column followed by the same letter or letters are not statistically different by LSD means $(P \leq 0.05)$.

May, $27.2^{\circ} \mathrm{C}$ in June, $26^{\circ} \mathrm{C}$ in July, $23.2^{\circ} \mathrm{C}$ in August, and $26^{\circ} \mathrm{C}$ in September) were significantly different from those in 2019 $\left(24^{\circ} \mathrm{C}\right.$ in May, $25.7^{\circ} \mathrm{C}$ in June, $27.3^{\circ} \mathrm{C}$ in July, $28.2^{\circ} \mathrm{C}$ in August, and $28.3^{\circ} \mathrm{C}$ in September). The temperatures were higher in 2018, coinciding with vegetative and early flowering stages, while 2019 had higher temperatures coinciding with the pod fill (R3-R7) stage. This could be one of the reasons for higher levels of protein and oil content in 2019.

Further, the pod fill period has overlapped with welldistributed rainfall (Figure 1) in August and September. Further, the yearly differences in seed constituents are attributable to the huge variation in GDD and solar radiation during the pod fill (R3-R7). The 2019 crop season received $58 \%$ higher solar radiation and 3\% higher GDD over that of the 2018 season during the same period. These results conform to the earlier detailed reports on the effect of temperature and soil moisture [11-13, 22]. An inverse curvilinear relationship between protein, oil, and air temperature during seed fill was reported earlier. Protein content increases when the air temperature is above $28^{\circ} \mathrm{C}$, and oil content increases up to $28^{\circ} \mathrm{C}$ and declines thereafter [13]. In this study, the oil content in the 2018 season was higher than in the 2019 season as the mean temperatures during seed fill (July-August) were below $28^{\circ} \mathrm{C}$, while 2019 had $3.2^{\circ} \mathrm{C}$ higher mean temperature than that of 2018 .

The enhanced protein content in irrigated treatment for both seasons could be due to higher leaf area index and canopy closure. Earlier publication from the same study [7] reported an $8-17 \%$ higher leaf area index (LAI) in irrigated treatments during flowering and seed development stages. The higher LAI contributing to the better interception of photosynthetically active radiation and early canopy closure could have led to increased $\mathrm{N}$ metabolism, resulting in a higher concentration of seed protein in irrigated treatments irrespective of PG. Furthermore, the increased protein accumulation is attributed to higher assimilates availability per developing seed and total assimilate supply per plant [23]. The other benefit of canopy closure is less plant-weed competition as canopy development suppresses weeds establishment near plant vicinity, thereby probably aiding the soybean plant to utilize the available moisture in the root zone efficiently. These results are similar to the findings of previous studies $[10,11,22]$. In the case of oil, RF soybean seed accumulated more oil than the irrigated treatments consistently in both years and conforms to the earlier published findings $[11,23]$. Among the sugars, only sucrose accumulation was significantly higher in RF soybean than irrigated, and sucrose is the major photosynthesis assimilation of plants and the fundamental carbon skeleton monomer and energy supplier for seed maturation. The sucrose allocation, metabolism, and transport during different seed formation, development, and maturation stages are implicated as one of the physiological mechanisms for soybean plants to overcome moisture stress, and higher sucrose accumulation was reported in soybean plants subjected to moisture stress [24]. The differential response of amino acids, that is, overaccumulation of ASP, GLU, GLY, CYS, and TYR in 2018 and 2019 seasons, can be not only due 
to irrigation but also due to temperature solar radiation and GDD resulting in higher LAI contributing to the better interception of photosynthetically active radiation and early canopy closure, which is in accordance with earlier reports $[6,10,22]$.

Unlike irrigation, PG has limited influence on seed constituents like stearic acid, sucrose, and amino acids, THR, GLU, GLY, CYS, ISO, LEU, ARG, and TRY. TR leads to higher LAI and thereby more photosynthates assimilation leading to higher accumulation of stearic acid, sucrose, and THR. As discussed earlier, higher nitrogen metabolism has probably contributed to high sucrose accumulation. However, the reasons for the decline of GLU, GLY, CYS, ISO, LEU, ARG, and TRY are not known. Similar findings were earlier reported by $[22,25]$.

\section{Conclusions}

Information on the effect of varying irrigation levels and PG on the pattern of accumulation of fatty acids, amino acids, and sugars in soybean grown in the Mississippi Delta is limited. This research demonstrated that both irrigation and PG can play a pivotal role in altering seed nutritional quality, which will impact farm profitability on a large scale by altering seed constituents: protein, oil, fatty acids, sugars, and few amino acids. The study also highlights the profound impact of environmental conditions like air temperature, solar radiation, and rainfall. Future research involving drought-tolerant varieties under varying levels of irrigation in multiyear and multilocation on large-scale field experiments could further advance our understanding of differential responses of seed composition constituents to crop management practices.

\section{Data Availability}

The raw data used to support the findings of this study are available from the corresponding author upon request.

\section{Conflicts of Interest}

The authors report no conflicts of interest.

\section{References}

[1] USDA-FAS, World Agricultural Outlook. WAP 12-20, USDAFAS, Washington, DC, USA, 2020, https://downloads.usda. library.cornell.edu/usda-esmis/files/5q47rn72z/cr56ns297/ 00000r529/production.pdf.

[2] R. Wilson, "Seed composition," in Soybeans: Improvement, Production and Uses, H. R. Boerma and J. E. Specht, Eds., pp. 621-677, Crop Science Society of America, Madison, WI, USA, 3rd edition, 2004.

[3] G. Rakow and D. I. McGregor, "Opportunities and problems in modification of levels of rapeseed C18 unsaturated fatty acids," Journal of the American Oil Chemists' Society, vol. 50, no. 10, pp. 400-403, 1973.

[4] A. Hou, P. Chen, J. Alloatti et al., "Genetic variability of seed sugar content in worldwide soybean germplasm collections," Crop Science, vol. 49, no. 3, pp. 903-912, 2009.
[5] N. Bellaloui, A. Mengistu, E. R. Walker, and L. D. Young, "Soybean seed composition as affected by seeding rates and row spacing," Crop Science, vol. 54, no. 4, pp. 1782-1795, 2014.

[6] N. Bellaloui, H. A. Bruns, H. K. Abbas, A. Mengistu, D. K. Fisher, and K. N. Reddy, "Effects of row-type, rowspacing, seeding rate, soil-type, and cultivar differences on soybean seed nutrition under US Mississippi delta conditions," PLoS One, vol. 10, no. 6, Article ID e0129913, 2015.

[7] S. Pinnamaneni, S. S. Anapalli, D. K. Fisher, and K. N. Reddy, "Irrigation and planting geometry effects on cotton (Gossypium hirsutum L.) yield and water use," Journal of Cotton Science, vol. 24, no. 2, pp. 87-96, 2020.

[8] S. R. Pinnamaneni, S. S. Anapalli, K. N. Reddy, D. K. Fisher, and N. E. Quintana-Ashwell, "Assessing irrigation water use efficiency and economy of twin-row soybean in the Mississippi Delta," Agronomy Journal, vol. 112, no. 5, pp. 4219-4231, 2020.

[9] H. Kebede, D. K. Fisher, R. Sui, and K. N. Reddy, "Irrigation methods and scheduling in the delta region of Mississippi: current status and strategies to improve irrigation efficiency," American Journal of Plant Sciences, vol. 5, no. 20, pp. 29172928, 2014.

[10] N. Bellaloui, H. A. Bruns, H. K. Abbas, A. Mengistu, D. K. Fisher, and K. N. Reddy, "Agricultural practices altered soybean seed protein, oil, fatty acids, sugars, and minerals in the Midsouth USA," Frontiers in Plant Science, vol. 6, 2015.

[11] N. Bellaloui and A. Mengistu, "Seed composition is influenced by irrigation regimes and cultivar differences in soybean," Irrigation Science, vol. 26, no. 3, pp. 261-268, 2008.

[12] B. F. Carver, J. W. Burton, T. E. Carter, and R. F. Wilson, "Response to environmental variation of soybean lines selected for altered unsaturated fatty acid composition 1," Crop Science, vol. 26, no. 6, pp. 1176-1181, 1986.

[13] D. L. Dornbos and R. E. Mullen, "Soybean seed protein and oil contents and fatty acid composition adjustments by drought and temperature," Journal of the American Oil Chemists Society, vol. 69, no. 3, pp. 228-231, 1992.

[14] S. R. Pinnamaneni, S. S. Anapalli, R. Sui, N. Bellaloui, and K. N. Reddy, "Effects of irrigation and planting geometry on cotton (Gossypium hirsutum L.) fiber quality and seed composition," Journal of Cotton Research, vol. 4, no. 1, p. 2, 2021.

[15] D. Desclaux and P. Roumet, "Impact of drought stress on the phenology of two soybean (Glycine max L. Merr) cultivars," Field Crops Research, vol. 46, no. 1-3, pp. 61-70, 1996.

[16] H. Q. Xue, R. G. Upchurch, and P. Kwanyuen, "Relationships between oleic and linoleic acid content and seed colonization by ercospora kikuchii and Didaporthe phaseolorum," Plant Disease, vol. 92, no. 7, pp. 1038-1042, 2008.

[17] K. Helrich, Official Methods of Analysis of the Association of Official Analytical Chemists (AOAC), AOAC, Rockville, MD, USA, 1990.

[18] N. Bellaloui, J. R. Smith, J. D. Ray, and A. M. Gillen, "Effect of maturity on seed composition in the early soybean production system as measured on near-isogenic soybean lines," Crop Science, vol. 49, no. 2, pp. 608-620, 2009.

[19] D. L. Pazdernik, A. S. Killam, and J. H. Orf, "Analysis of amino and fatty acid composition in soybean seed, using near infrared reflectance spectroscopy," Agronomy Journal, vol. 89, no. 4, pp. 679-685, 1997.

[20] J. Fontaine, "Amino acid analysis of feeds," in Amino Acids in Animal Nutrition, pp. 15-40, CABI, Cambridge, MA, USA, 2003. 
[21] P. W. G. Sale and L. C. Campbell, "Changes in physical characteristics and composition of soybean seed during crop development," Field Crops Research, vol. 3, pp. 147-155, 1980.

[22] B. Nacer, M. Angela, A. M. McClure, and H. K. Abbas, "The influence of different agricultural practices, the environment and cultivar differences on soybean seed protein, oil, sugras and amino acids," Plants, vol. 68, pp. 161-172, 2020.

[23] J. L. Rotundo, L. Borrás, M. E. Westgate, and J. H. Orf, "Relationship between assimilate supply per seed during seed filling and soybean seed composition," Field Crops Research, vol. 112, no. 1, pp. 90-96, 2009.

[24] Y. Du, Q. Zhao, L. Chen et al., "Effect of drought stress during soybean R2-R6 growth stages on sucrose metabolism in leaf and seed," International Journal of Molecular Sciences, vol. 21, no. 2, p. 618, 2020.

[25] E. Boydak, M. Alpaslan, M. Hayta, S. Gerçek, and M. Simsek, "Seed composition of soybeans grown in the Harran region of Turkey as affected by row spacing and irrigation," Journal of Agricultural and Food Chemistry, vol. 50, no. 16, pp. 47184720, 2002. 